\title{
Biomineralization Induced by Cells of Sporosarcina pasteurii: Mechanisms, Applications and Challenges
}

\author{
Yang $\mathrm{Wu} * \mathbb{C}$, Huimin Li and Yang $\mathrm{Li}$ \\ School of Chemical Engineering and Technology, Tianjin University, Tianjin 300072, China; \\ 2014207404@tju.edu.cn (H.L.); ywu@tju.edu.cn (Y.L.) \\ * Correspondence: yangw@tju.edu.cn; Tel.: +86-177-3212-2306
}

\begin{abstract}
Biomineralization has emerged as a novel and eco-friendly technology for artificial mineral formation utilizing the metabolism of organisms. Due to its highly efficient urea degradation ability, Sporosarcina pasteurii (S. pasteurii) is arguably the most widely investigated organism in ureolytic biomineralization studies, with wide potential application in construction and environmental protection. In emerging, large-scale commercial engineering applications, attention was also paid to practical challenges and issues. In this review, we summarize the features of S. pasteurii cells contributing to the biomineralization reaction, aiming to reveal the mechanism of artificial mineral formation catalyzed by bacterial cells. Progress in the application of this technology in construction and environmental protection is discussed separately. Furthermore, the urgent challenges and issues in large-scale application are also discussed, along with potential solutions. We aim to offer new ideas to researchers working on the mechanisms, applications and challenges of biomineralization.
\end{abstract}

Keywords: biomineralization; Sporosarcina pasteurii; urease; construction material; removal of heavy metals

Citation: Wu, Y.; Li, H.; Li, Y

Biomineralization Induced by Cells of Sporosarcina pasteurii: Mechanisms, Applications and Challenges. Microorganisms 2021, 9, 2396. https://doi.org/10.3390/ microorganisms 9112396

Academic Editor: Giovanni Vallini

Received: 3 November 2021

Accepted: 19 November 2021

Published: 21 November 2021

Publisher's Note: MDPI stays neutral with regard to jurisdictional claims in published maps and institutional affiliations.

Copyright: (c) 2021 by the authors. Licensee MDPI, Basel, Switzerland. This article is an open access article distributed under the terms and conditions of the Creative Commons Attribution (CC BY) license (https:// creativecommons.org/licenses/by/ $4.0 /)$.

\section{Introduction}

Biomineralization is a mineral-generating process catalyzed by the metabolism of organisms, which can harden the cells or the surrounding matrix to provide protection [1] and bracing [2]. Examples of biomineralization are widely found from microbes to animals, and can be witnessed throughout nature in the form of bones [3], shells [4], corals [5], as well as certain rocks and minerals [6]. More than 60 minerals are known to be formed by biomineralization, including ferric oxide, manganese oxide and other metal oxides.

According to the formation mechanism, biomineralization processes could be divided into two categories: biologically controlled mineralization (BCM) and biologically induced mineralization (BIM) [7]. In BCM, the location or structure of the synthetic biominerals is directly controlled by cells. As a typical example, magnetic iron biominerals can be precisely synthesized by magnetotactic bacteria as intracellular magnetosomes for sensing the geomagnetic field, and these particles have also been applied in the control and remediation of environmental pollution [8]. Arguably the most common biomineral, bone, is also synthesized in a precisely controlled manner by osteoblasts, which express alkaline phosphatase to hydrolyze pyrophosphate and provide inorganic phosphate for the formation of calcium phosphate in the bone matrix [9].

By contrast, BIM biominerals are formed due to chemical alterations of the local environment, which is induced by the metabolic activity of organisms. Thus, the locations and structures of BIM minerals are not controlled by cells. Recently, numerous BIM strategies have been developed using different organisms, including calcite precipitation by urea hydrolysis of ureolytic bacteria [10], carbonates formation by asparagine hydrolysis of Bacillus megaterium [11] and sulfide precipitation by sulfate reduction of sulfate-reducing bacteria $[12,13]$. Among these strategies, ureolytic bacteria are considered one of the most widely applicable due to their simple functional principle in urea hydrolysis catalyzed by urease 
and environmentally friendly performance in carbon neutrality $[10,14]$. Consequently, ureolytic biomineralization has been adopted for numerous applications in construction and environmental protection, such as self-healing concrete [15], bio-bricks [16], dust stabilization [17], ground improvement [18] and bioremediation [19].

Sporosarcina pasteurii (S. pasteurii) is a Gram-positive bacterium isolated from soil. It requires urea and ammonium for growth and has the ability to form spores in the harsh environmental conditions to enhance its survival. Among ureolytic microorganisms, S. pasteurii is the most frequently used strain in biomineralization due to its ultra-high urease activity. As shown in Table 1, the $\mathrm{Km}$ values of urease from different microorganisms are listed. The value of $\mathrm{Km}$ is the Michaelis constant, equal to the substrate concentration at which the reaction rate is half of the maximum rate in the enzymatic system. The $\mathrm{Km}$ is a measure of how efficiently an enzyme converts a substrate into a product. Notably, the urease of $S$. pasteurii is among the most active reported enzymes and constitutes up to $1 \%$ of a cell's dry weight, leading to a distinct advantage for ureolytic biomineralization [20]. The process of microbially induced calcite precipitation (MICP) by S. pasteurii is schematically illustrated in Figure 1. Urease is expressed in cells and catalyzes the hydrolysis of urea to form ammonia and carbon dioxide. The ammonia leads to an increase in $\mathrm{pH}$ and carbon dioxide provides sufficient carbonate ions for calcium carbonate precipitation. Finally, the cell surface gathers calcium ions due to negatively charged groups and acts as the nucleation site of precipitates in MICP [21]. With the increasing consciousness of energy conservation and environmental protection in recent years, biomineralization using S. pasteurii cells has gained increasing attention among scientists, with potential applications in construction, environmental protection and medicine [22]. However, there are still challenges in both science and engineering that need to be addressed. For example, in studies on the dynamic growth of precipitates, conflicting mechanisms were still reported in recent years. Zhang et al. denied the role of the bacterial cell surface as nucleation sites during MICP [23], while Ghost et al. reconfirmed that precipitates are deposited on the cell surface using different methods [24]. In practical applications, many factors still need to be optimized for cost-effectiveness and scale-up. To our knowledge, the biomineralization induced by $S$. pasteurii cells have not been comprehensively summarized and reviewed in detail to date.

Table 1. Urease activity of different microorganisms.

\begin{tabular}{cc}
\hline Microorganism & Km of Urease (mol/L) \\
\hline Sporosarcina pasteurii & $40-130[25]$ \\
Brevibacterium ammoniagenes & $18-72[26]$ \\
Providencia stuartii & $10.50-71[27]$ \\
Proteus mirabilis & $13[28]$ \\
Arthrobacter oxydans & $12.50[29]$ \\
Staphylococcus saprophyticus & $7.36[30]$ \\
Klebsiella aerogenes & $2.80[31]$ \\
Aspergillus nidulans & $1.33[32]$ \\
Spirulina maxima & $0.12[33]$ \\
\hline
\end{tabular}

The purpose of this review is to give an overview of the biomineralization induced by $S$. pasteurii cells in terms of mechanisms, applications and challenges. We focus on the specific features of $S$. pasteurii cells contributing to biomineral formation, aiming to reveal the mechanism through which bacterial cells catalyze the biomineralization reactions. Furthermore, numerous applications in construction and environmental protection are summarized and discussed in detail, with the aim of expanding the potential to more possible fields. Finally, the urgent challenges and issues in large-scale application of a non-uniform biomineral structure, ammonia pollution and cost optimization are discussed, along with potential solutions. This review provides a reference to improve the scope and efficiency of studies on biomineralization. 


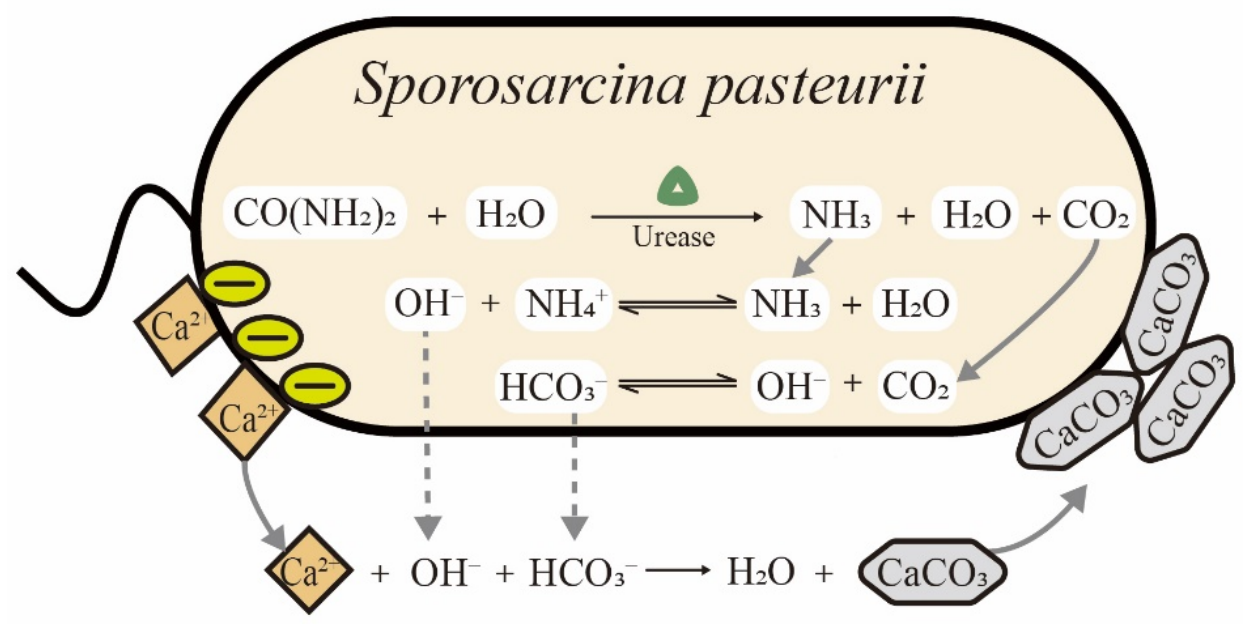

Figure 1. Schematic of microbially induced calcite precipitation (MICP) catalyzed by S. pasteurii cells.

\section{Special Features of S. pasteurii Cells in Biomineralization}

Biomineralization efficiency is mainly determined by four factors-calcium, inorganic carbon, $\mathrm{pH}$ and nucleation sites [34]. S. pasteurii has multiple features that enable efficient biomineralization, including high urease activity, negatively charged surface, spore formation and weak mobility. As shown in Figure 2, these features play roles in the key dimensions of biomineralization. Here, we summarize and discuss these biological peculiarities and biomineralization functions of $S$. pasteurii cells.

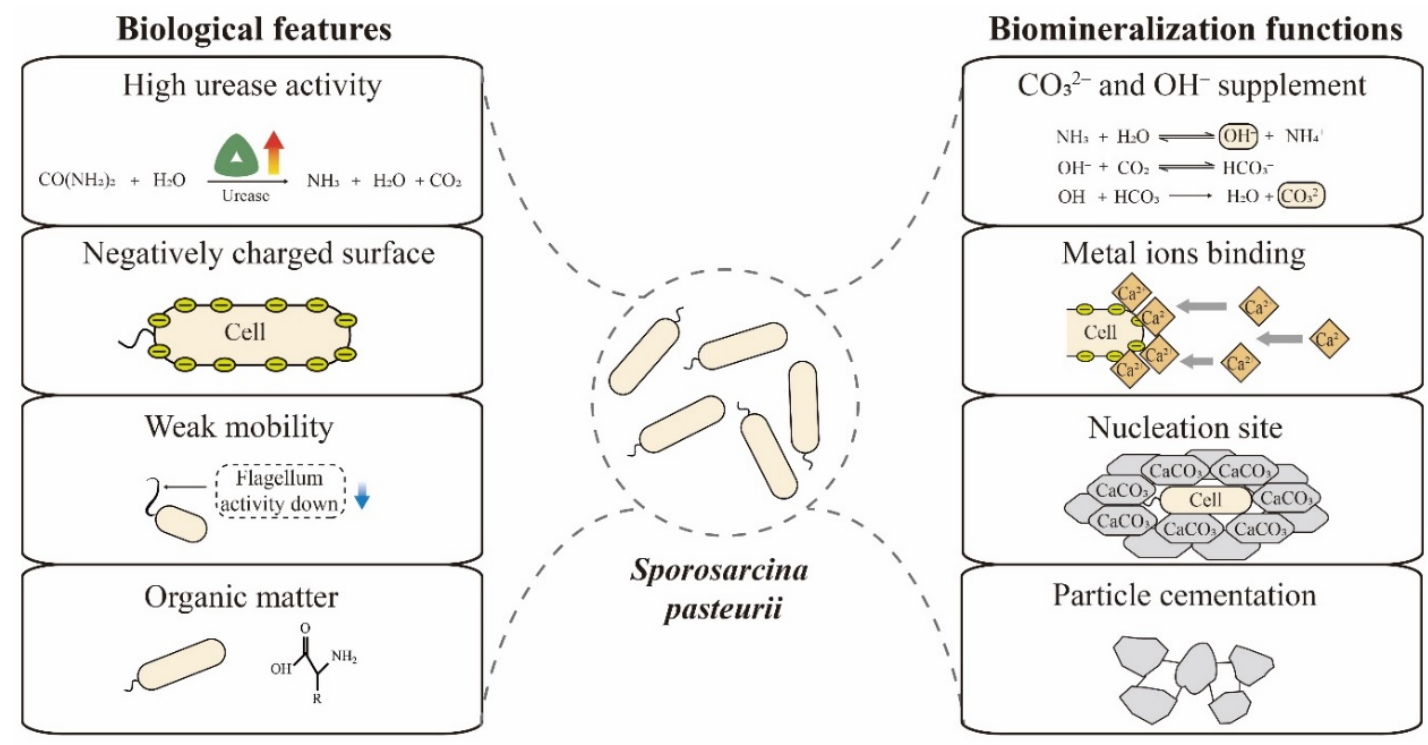

Figure 2. Relevant biological features and biomineralization functions of S. pasteurii cells.

\subsection{Urea Hydrolysis}

Since S. pasteurii was isolated from soil, its ultra-high urease activity has drawn extensive attention from researchers, and it can provide sufficient carbonate and hydroxyl ions for biomineralization (Figure 2). In order to investigate the mechanism of ultra-high urease activity, the structure, function and enzymatic properties of urease were researched comprehensively [35]. The urease from S. pasteurii cell is a nickel-dependent enzyme with a trimeric structure, in which each monomer contains one large ( $\alpha$ subunit UreA) and two small subunits ( $\beta$ subunit UreB and $\gamma$ subunit UreC) [36]. Moreover, four auxiliary proteins, UreD, UreE, UreF and UreG, are also necessary for urease assembly. The assembly 
process consists of three steps according to the reported hypothesis [20,37]. Firstly, the three-subunit complex, UreABC, is expressed from the genome and self-assembled. At the same time, the auxiliary protein complex, UreDFG, is also expressed and formed as another three-subunit complex. Subsequently, UreABC-UreaDFG is assembled as the final supercomplex. Finally, the metallochaperone UreE transfers the nickel ion into the active center of the UreABC-UreDFG complex and completes the activation of ureolytic activity [38].

Among the auxiliary proteins, UreE is the only nickel-binding protein and the key factor for urease activation. However, the definite dynamics of nickel loading and urease assembly has not been fully understood to date. In computational simulation studies, Carlsson et al. presented a DFT-based calculation method to study the urease mechanism and found that the binding site of the urea substrate included the nickel ion in the active center [39]. In experimental studies, Won et al. reported that the conserved side chain at the C-terminus of UreE serves as a ligand of the nickel ion. Furthermore, the nickel ion content of urease decreased dramatically in the absence of UreE, leading to enzyme inactivation [40]. Similarly, Scott et al. performed knockout studies of partial sequences in the ureE gene, causing about a 50\% decline in ureolytic activity [41]. By contrast, there are limited reports investigating the other auxiliary proteins, including UreD, UreF and UreG. Liu et al. expressed the UreABC genes in E. coli and improved urease activity about 5-6 times by the co-expression of UreDFG, demonstrating the importance of UreDFG for urease activity [42].

The ultra-high ureolytic activity is also related to the metabolic mechanism of S. pasteurii cells. On the one hand, generation of the proton electrochemical potential by ureolysis has been speculated to be an ATP production pathway in S. pasteurii cells, as shown in Figure $3[43,44]$. In detail, $\mathrm{NH}_{4}{ }^{+}$produced from intracellular urea hydrolysis spreads to the extracellular space. The reversible balance ratios of $\mathrm{NH}_{4}{ }^{+}$generating $\mathrm{NH}_{3}$ and $\mathrm{H}^{+}$ are different in intracellular and extracellular environments, at 70:30 and 50:50 of $\mathrm{NH}_{4}^{+}$ vs. $\mathrm{NH}_{3}$, respectively. Finally, the proton concentration gradient of more extracellular $\mathrm{H}^{+}$ results in a proton motive force to drive ATP synthase for energy generation. Recently, this hypothesis was further confirmed by transcriptome analysis. Ma et al. reported that the genes for ATPase synthesis were upregulated in the MICP process or a urea-deficient environment, implying the relationship between ATP and urease [21]. Pei et al. also elucidated that urea hydrolysis might promote the synthesis of intracellular ATP and the cells could not grow normally in the absence of urea [45]. On the other hand, a survival advantage was also observed in S. pasteurii cells that utilize the urea hydrolysis process. Specifically, massive amounts of $\mathrm{NH}_{3}$ and $\mathrm{OH}^{-}$were generated during urea hydrolysis, increasing the ammonia concentration and $\mathrm{pH}$ value in the environment. Consequently, competing organisms that are sensitive to ammonia or an alkaline solution would be killed, while $S$. pasteurii cells could survive due to their high alkali and ammonia resistance [46].

Recently, strains with enhanced urease activity were obtained by plasma mutagenesis and UV irradiation, significantly increasing the amount of precipitated calcium carbonate in MICP [47,48]. Overall, although the urease dynamics and metabolic mechanism of $S$. pasteurii cells still need to be elucidated more clearly, the ultra-high ureolytic activity has been investigated and utilized for carbonate and hydroxyl ion supply in biomineralization. 


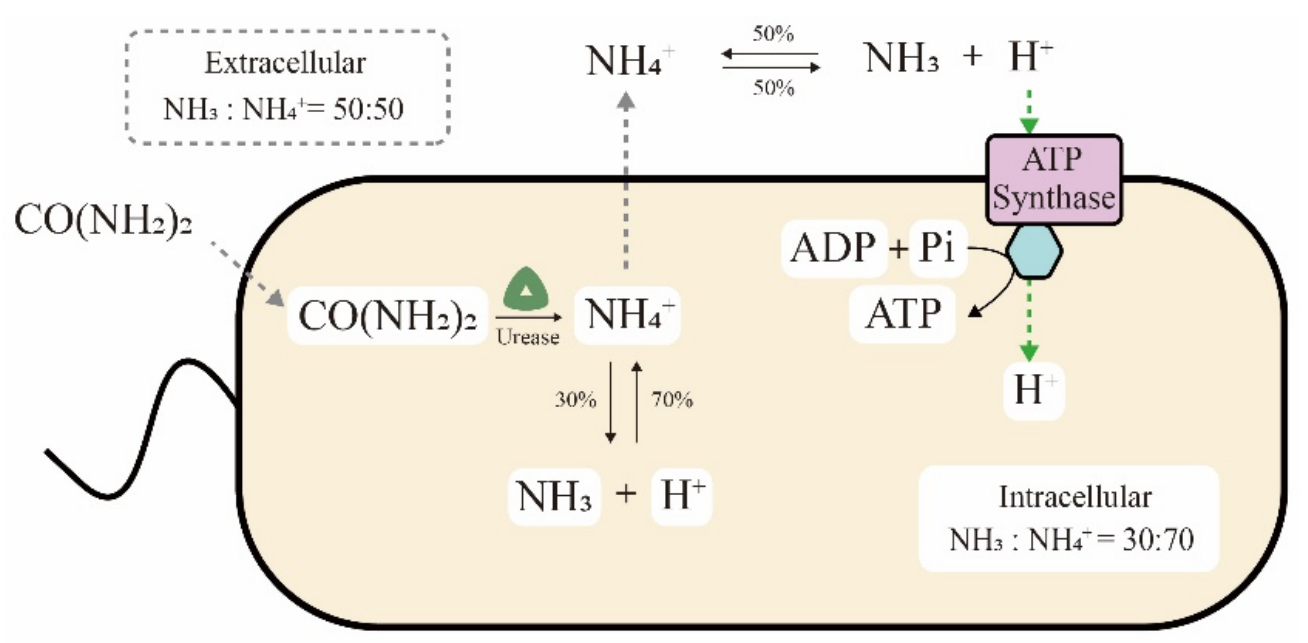

Figure 3. ATP generation through the proton electrochemical potential induced by urea hydrolysis.

\subsection{Precipitate Nucleation}

Nucleation is a key process in biomineral formation, which requires nucleation sites and sufficient reactive ions to form the insoluble precipitate [49]. Coincidentally, S. pasteurii cells could provide these conditions efficiently. In biomineralization, the negatively charged surface of bacterial cells could bind cations (metal ions) and create a regional ion-saturated microenvironment to satisfy the nucleation requirements [50]. Moreover, S. pasteurii cells have been reported to have more negative surface charges than non-mineralizing bacteria such as Bacillus subtilis, Staphylococcus aureus and Escherichia coli, which could greatly benefit the nucleation step [21].

The bacterial cell surface has been revealed to act as a nucleating site in biomineralization through various approaches. Utilizing ultramicrosensor detection, Harris et al. observed the precipitation of biominerals on the surface of $S$. pasteurii cells during the MICP process, suggesting the involvement of the cell surface in the nucleation process [51]. Transcriptome analysis revealed decreased flagellar gene expressions in S. pasteurii cells during biomineralization, which could inhibit cell mobility and improve the effectiveness of cells serving as the nucleation sites [21]. Moreover, Ghost et al. found conclusive evidence that nanoscale crystals formed on the bacterial cell surface using scanning electron microscopy (SEM) and transmission electron microscopy (TEM) [24]. Nonetheless, some contradictory perspectives were still reported in recent years. Zhang et al. denied the role of the bacterial cell surface as a nucleation site during MICP based on an in situ real-time study at the single-cell resolution with the recorded grain sizes, which was contradictory to the above investigations [23]. Hence, the nucleation process induced by bacterial cells may be more complicated than reported, requiring more definite studies in the future. For example, the quantitative parameters of nucleation were required in quantitative analysis. However, to the best of our knowledge, microscopy techniques, SEM and TEM, were the main methods in biomineralization researches. Thus, the recorded grain sizes were the only quantitative parameters in this process. Indeed, more quantitative parameters need to be developed in the future.

\subsection{Biomineral Cementation and Spore Formation}

Microbial cementation is a fundamental step in the binding of loose particles in the form of sandstone in some biomineralization applications, which can improve the mechanical properties of biominerals. However, such cementation was not witnessed in traditional chemical precipitation, suggesting additional effects of the microbial cells in biomineral cementation [52].

In order to investigate the cementation mechanism of microbes in biomineralization, a serious of efforts have been made in recent years. Rong et al. compared different sand 
columns prepared using biological or chemical approaches and found that only the biological sand column transformed into a solid material with remarkable strength [53]. Subsequently, mechanisms of biomineral cementation were explored by numerous approaches, including nuclear magnetic resonance (NMR), X-ray photoelectron spectroscopy (XPS), infrared spectroscopy (IR) and TEM. The results indicated that additional hydrogen bonds were generated between particles during the biomineralization process, which might contribute to the cementation function [54]. Based on a study of the cementation interface of bio-cement, Qian et al. concluded that hydrogen bonds were formed between the hydroxide radicals of polypeptides on the cell surface and oxygen atoms of oxide minerals, so that the cementation was a result of the combined effects of microbes and minerals. For example, in the biomineralization of a sand column, the hydrogen bonds were supposed to be formed between the oxygen in the silica and the peptides in the organic matter for biomineral cementation [55].

Additionally, spore formation of the Gram-positive S. pasteurii cells also improves their tolerance of extreme environmental conditions, such as nutrient deficiencies, extreme temperatures and $\mathrm{pH}$ values [56]. This ability to form spores is indirectly related to biomineralization. However, such long-term viability of bacteria opens the possibility of long-term biomineralization reactions in extreme applications, including self-healing concrete [57] and the bioremediation of metal ions [58]. Notably, the non-spore-forming Gram-positive bacterium Staphylococcus pasteurii was also isolated and tested in biomineralization investigations. Compared with S. pasteurii cells, the survival time of Staphylococcus pasteurii in the soil was much shorter due to the absence of spore formation [59].

\section{Applications of Biomineralization}

With the discussed advantages of $S$. pasteurii cells, ureolytic biomineralization has been successfully applied in construction and environment protection, improving the scope and efficiency of environmentally friendly techniques. Here, we discuss the challenges and opportunities of these current and emerging applications.

\subsection{Construction Applications}

Undeniably, most applications of biomineralization technology can be found in construction. Extensive studies have been carried out for potential applications in both the construction and repair of buildings using S. pasteurii cells, including the typical examples of self-healing concrete and bio-bricks.

The increasing cracks and holes in aging concrete structures can seriously compromise the safety and tightness of constructions, leading to expensive repairs or reconstruction. In order to address this issue, traditional concrete was suggested to be replaced with a novel self-healing concrete, which could automatically heal the cracks through biomineralization (Figure 4A) [60,61]. The first examples of self-healing concrete were composed of S. pasteurii cells, calcium ions, nutrients, concrete and other supplements. The bacterial spores could survive up to 10 years in the concrete matrix [61]. Once cracks appear, the rainwater that seeps into the cracks would activate spores to fill the space of the cracks via a biomineralization reaction, achieving the goal of self-healing [62]. However, certain additives in self-healing concrete, such as bacterial cells, nutrients and calcium supplements, might also compromise the performance of the concrete [63]. Recently, several studies focused on the optimization of self-healing concrete for performance enhancement. For instance, Chen et al. investigated the influence of the S. pasteurii cell concentration on the self-healing properties, and suggested $2 \times 10^{6}$ cells $/ \mathrm{mL}$ as the proper bacterial concentration [64]. Kang et al. proposed calcium lactate as nutrient and calcium supplement for S. pasteurii cells, avoiding damaging the hardness of the concrete due to traditional saccharide nutrients [65]. Furthermore, some additional additives were included to improve self-healing concrete, including polyurethane, silica gel and air-entraining agents [66-69]. 


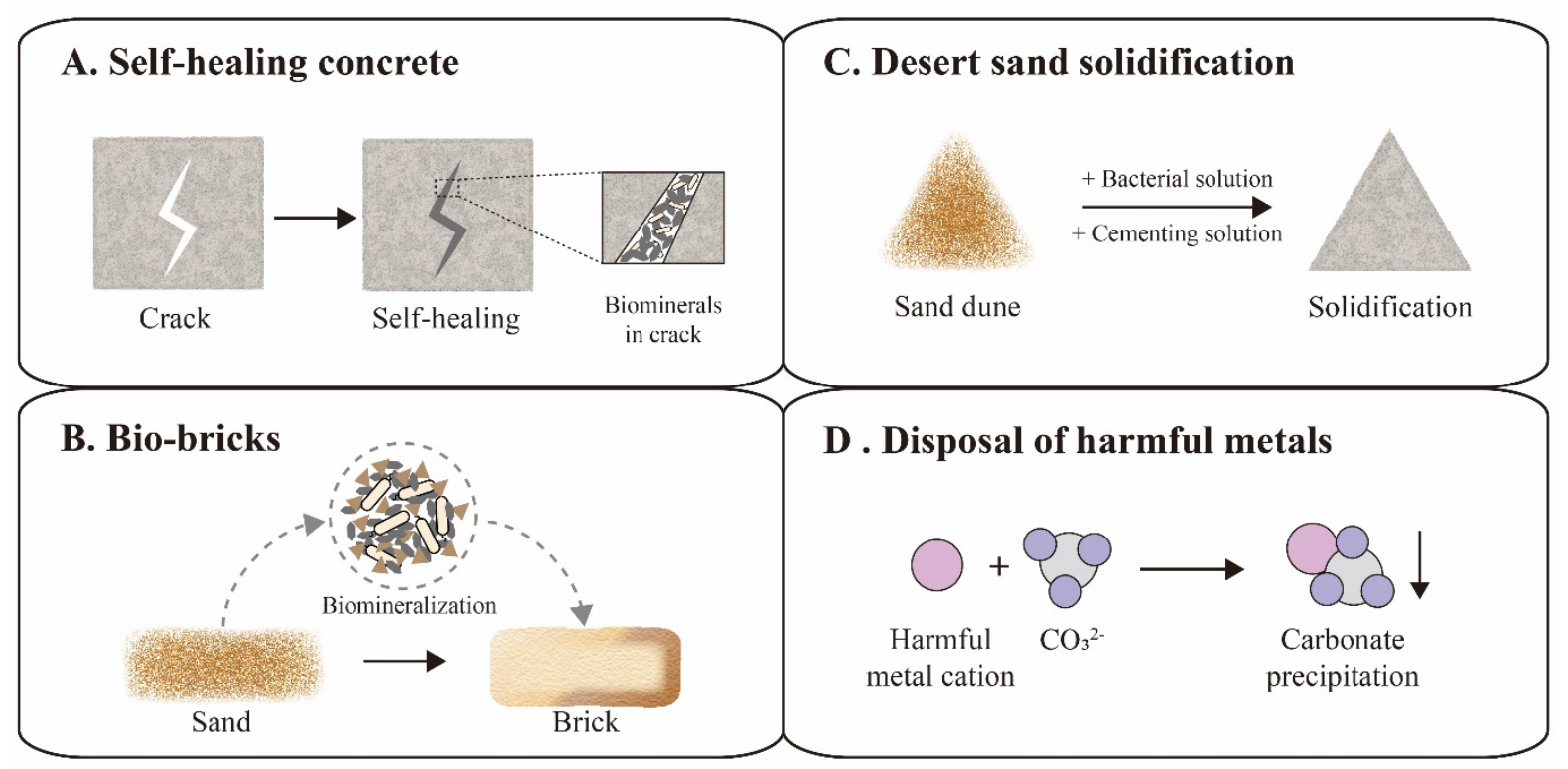

Figure 4. Applications of ureolytic biomineralization. Self-healing concrete (A) and bio-bricks (B) are representative cases in the construction field. Desert sand solidification $(C)$ and disposal of harmful metals (D) are representative cases in the environmental protection field.

In addition to self-healing concrete, brick manufacturing has also applied novel biomineralization technology, called bio-bricks. In 2012, the BioMason company was founded for bio-brick research and development using S. pasteurii cells [70]. Their patented bio-brick "bioLITH ${ }^{\circledR}$ tiles" are available now in practical building construction. In the manufacturing process, these bio-bricks are cultured in custom shaped molds, where sand is mixed with bacterial cells and cemented into a whole by the biomineralization reaction (Figure 4B) [71]. Recently, the bio-brick technique was developed for better performance and cost-effectiveness by numerous efforts. Li et al. investigated the effects of different additives on the properties of bio-bricks, and found that fiber supplements could increase the compression strength of the bio-brick by $50-70 \%$ [72]. Lambert et al. successfully grew the world's first bio-brick from human urine instead of chemical urea, reducing production costs [73].

Additionally, the technology of biomineralization has been applied in oil-well plugging [74], solidification of riverbanks [75] and rescue of historical buildings [76]. These aging structures have undergone deterioration due to chemical and physical weathering, requiring restoration of cracks and holes. Then, S. pasteurii cells and supplements were injected and utilized to generate biominerals as a stuffing or adhesive for the damaged areas, accomplishing the purpose of a life-expectancy extension of existing structures.

\subsection{Environmental Applications}

In addition to applications in the construction industry, biomineralization was also employed in environmental protection applications, such as desert solidification and removal of harmful metals. Desert expansion and resulting loss of farmland is a worldwide problem, requiring widely applicable solutions [77]. Although numerous chemical approaches have been proposed for desert sand stabilization, the costs and labor intensity still need to be reduced in view of the vastness of desert areas. Recently, biomineralization was developed as an environmentally friendly and cost-effective method for sand stabilization by simulating natural processes (Figure 4C). Katebi et al. spread a cementation solution containing S. pasteurii cells on the sand surface, which resulted in a stable sand crust at the field scale in the desert [78]. A similar strategy was also applied for the solidification of fly ash into a green sustainable material, increasing the compressive strength up to $43.75 \%$ [79]. Looking forward, Larsson et al. envisioned bold plans to solidify Sahara sand to build 
comfortable shelters for humans and prevent the spreading of the desert, illustrating the vast potential of biomineralization in environmental stewardship [80].

Harmful metal disposal is emerging to be a great challenge to environmental remediation, which seriously threaten human health [81]. Fortunately, a biomineralization reaction induced by $S$. pasteurii cells could provide sufficient $\mathrm{CO}_{3}{ }^{2-}$ ions to integrate these metal cations into undissolving carbonate for easy removal (Figure 4D) [82]. Soils contaminated with strontium $(\mathrm{Sr})$ or lead $(\mathrm{Pb})$ were successfully removed by biomineralization of $S$. pasteurii cells with more than $99 \%$ efficiency [83]. Recently, multiple heavy metals, such as cadmium $(\mathrm{Cd})$, zinc $(\mathrm{Zn})$ and copper $(\mathrm{Cu})$, were also reported to be eliminated from soils using biomineralization technology $[84,85]$. This bioremediation technology has become an attractive solution for the removal of harmful metals. In general, biomineralization mimics the natural biogeochemical carbon cycle, which could revolutionize sustainable industries and create an environmentally friendly society in the future.

\section{Challenges and Issues}

Although there are increasing numbers of reports demonstrating the potential of biomineralization applications in numerous fields, large-scale commercial projects are still restricted by several key limitations, including a non-uniform biomineral structure, ammonia pollution and cost optimization. In this part, the challenges and issues of biomineralization in practical applications will be summarized and discussed.

\subsection{Non-Uniform Biomineral Structure}

Uniformity is a basic requirement of products with stable performance in a wide range of applications. However, in large-scale biomineralization, different degrees of a reaction always appear in different areas of the product, leading to non-uniform structures with uncertain performance [86]. Qian et al. investigated large-scale biomineralization by injecting S. pasteurii cells and supplementary solutions into a 125-L sand column. Analysis of both the calcite content and compressive strength of the sand column indicated the uneven distribution of biominerals, whereby there was reduced biomineralization farther from the injection point [87]. At the injection point, biominerals were quickly formed with freshly injected cells and solutions, blocking fluent inflow of subsequent solutions and leading to non-uniform biomineralization reactions [88].

To address this intractable issue, several strategies were proposed recently. On the one hand, the concentrations of ingredients in the injection solutions were optimized to reduce the reaction rate for uniform biomineralization. Salwa et al. reduced the $\mathrm{Ca}^{2+}$ concentration and obtained a one-meter homogeneous sand column with 5.9 MPa of compressive strength [89]. Similarly, a bacterial solution with an $\mathrm{OD}_{600}$ of 1.0 was selected to prepare a more uniform biomineral with higher strength [90]. On the other hand, efforts were also made in the optimization of the injection of bacterial or supplementary solutions [91]. Rong et al. confirmed that a slow rate of bacterial solution flow $(5 \mathrm{~mL} / \mathrm{min})$ contributed to uniform product mineralization by preventing the blockage caused by a quick reaction at the injection point [92]. Tobler et al. presented a new method of injecting bacterial and supplementary solutions at different positions of the sand column, which resulted in a uniform distribution of biominerals in the product [93]. However, practical field-scale verification of these laboratorial strategies is still needed before commercial applications can be considered [94].

\subsection{Ammonia Pollution}

Biomineralization via urea hydrolysis induced by S. pasteurii cells produces large amounts of ammonia as a by-product, which leads to environmental pollution with toxic effects on ecosystems, vegetation and human health [95]. To overcome this problem, researchers also tested non-ureolytic bacteria. For example, Zhu et al. replaced S. pasteurii with the photosynthetic bacterium Synechococcus PCC8806, to generate $\mathrm{HCO}_{3}{ }^{-}$for carbonate precipitation without ammonia emissions [96]. Notably, a ureolytic biominer- 
alization method without ammonia emission was recently proposed based on struvite precipitation induced by S. pasteurii, which locks ammonium in the final product, avoiding pollution [97]. This might be an appropriate solution to encourage large-scale applications of biomineralization after the necessary validation studies.

\subsection{Cost Optimization}

On the laboratory scale, high-grade reagents such as nutrient sources and pure urea were used in most studies of biomineralization, irrespective of costs. However, the cost of commercial projects is a crucial limitation in the large-scale application of biomineralization, requiring economical alternatives to these laboratory reagents. Fortunately, several costeffective alternatives were discovered and analysed. As a nutrient source, some waste products of the food industry are suitable substitutes typically found at a bargain price and in large amounts, including whey powder from cheese production $[98,99]$, lactose from the dairy industry [100] and corn steep liquor from corn starch processing [101]. Additionally, chicken manure was also utilized as a cultivation medium for S. pasteurii cells [102]. Kitchen waste is also an alternative nutrient source for the culture of bacterial cells [103]. As a replacement for highly pure synthetic urea, both pig urine and human urine were investigated in biomineralization for cost reduction [16,104]. Even distilled water was successfully replaced with Caspian seawater, saving costs during the large-scale distilled water preparation of biomineralization [98]. Looking forward, more sources and proportions of other components, such as calcium and supplementary reagents, still require further optimization for low-cost and high-quality applications [90,105].

\section{Conclusions}

Biomineralization induced by S. pasteurii cells has emerged as a powerful technology with booming research on its mechanisms, applications and challenges, which were firstly summarized in this review. Due to the advantages of ultra-high urease activity, negatively charged surface, spore formation and weak mobility, S. pasteurii cells are considered an ideal strain for the key processes of urea hydrolysis, precipitating nucleation and biomineral cementation in ureolytic biomineralization. Moreover, numerous novel applications, such as self-healing concrete, bio-bricks, desert sand solidification and disposal of harmful metals, were developed rapidly in the construction and environmental protection fields, illustrating the vast future potential of biomineralization. In large-scale engineering, the challenges and issues of a nonuniform biomineral structure, ammonia pollution and cost optimization were discussed in terms of current progress and urgently needed further solutions. Efforts should be made to shore up these weak spots in future studies. By emphasizing these crucial aspects of biomineralization induced by S. pasteurii cells, this review is intended to provide a bridge between current research and future commercialscale applications in this rapidly developing field, assisting both scientists and engineers in their studies on mechanisms, applications and challenges.

Author Contributions: Y.W. conceived the idea, drafted the original manuscript, and designed the figures. H.L. and Y.L. revised and improved the manuscript. All authors have read and agreed to the published version of the manuscript.

Funding: This research received no external funding.

Institutional Review Board Statement: Not applicable.

Informed Consent Statement: Not applicable.

Conflicts of Interest: The authors declare no conflict of interest. 


\section{References}

1. Zerfass, C.; Christie-Oleza, J.A.; Soyer, O.S. Manganese Oxide Biomineralization Provides Protection against Nitrite Toxicity in a Cell-Density-Dependent Manner. Appl. Environ. Microbiol. 2019, 85, e2129-18. [CrossRef] [PubMed]

2. Athanasiadou, D.; Carneiro, K.M.M. DNA nanostructures as templates for biomineralization. Nat. Rev. Chem. 2021, 5, 93-108. [CrossRef]

3. Zhang, J.; Tang, L.; Qi, H.; Zhao, Q.; Liu, Y.; Zhang, Y. Dual Function of Magnesium in Bone Biomineralization. Adv. Health Mater. 2019, 8, e1901030. [CrossRef]

4. Song, X.; Liu, Z.; Wang, L.; Song, L. Recent Advances of Shell Matrix Proteins and Cellular Orchestration in Marine Molluscan Shell Biomineralization. Front. Mar. Sci. 2019, 6. [CrossRef]

5. Zaquin, T.; Malik, A.; Drake, J.L.; Putnam, H.M.; Mass, T. Evolution of Protein-Mediated Biomineralization in Scleractinian Corals. Front. Genet. 2021, 12, 618517. [CrossRef]

6. Cohen, P.A.; Strauss, J.V.; Rooney, A.D.; Sharma, M.; Tosca, N. Controlled hydroxyapatite biomineralization in an $~ 810$ millionyear-old unicellular eukaryote. Sci. Adv. 2017, 3, e1700095. [CrossRef]

7. Lowenstam, H.A. Minerals formed by organisms. Science 1981, 211, 1126-1131. [CrossRef]

8. Wang, X.; Li, Y.; Zhao, J.; Yao, H.; Chu, S.; Song, Z.; He, Z.; Zhang, W. Magnetotactic bacteria: Characteristics and environmental applications. Front. Environ. Sci. Eng. 2020, 14, 56. [CrossRef]

9. Orimo, H. The mechanism of mineralization and the role of alkaline phosphatase in health and disease. J. Nippon Med. Sch. 2010, 77, 4-12. [CrossRef] [PubMed]

10. Arias, D.; Cisternas, L.; Rivas, M. Biomineralization Mediated by Ureolytic Bacteria Applied to Water Treatment: A Review. Crystals 2017, 7, 345. [CrossRef]

11. Li, M.; Fu, Q.L.; Zhang, Q.; Achal, V.; Kawasaki, S. Bio-grout based on microbially induced sand solidification by means of asparaginase activity. Sci. Rep. 2015, 5, 16128. [CrossRef] [PubMed]

12. Braissant, O.; Decho, A.W.; Dupraz, C.; Glunk, C.; Przekop, K.M.; Visscher, P.T. Exopolymeric substances of sulfate-reducing bacteria: Interactions with calcium at alkaline $\mathrm{pH}$ and implication for formation of carbonate minerals. Geobiology 2007, 5, 401-411. [CrossRef]

13. Venzlaff, H.; Enning, D.; Srinivasan, J.; Mayrhofer, K.J.J.; Hassel, A.W.; Widdel, F.; Stratmann, M. Accelerated cathodic reaction in microbial corrosion of iron due to direct electron uptake by sulfate-reducing bacteria. Corros. Sci. 2013, 66, 88-96. [CrossRef]

14. Krajewska, B. Urease-aided calcium carbonate mineralization for engineering applications: A review. J. Adv. Res. 2018, 13, 59-67. [CrossRef] [PubMed]

15. Chen, H.-J.; Chen, M.-C.; Tang, C.-W. Research on Improving Concrete Durability by Biomineralization Technology. Sustainability 2020, 12, 1242. [CrossRef]

16. Randall, D.G.; Naidoo, V. Urine: The liquid gold of wastewater. J. Environ. Chem. Eng. 2018, 6, 2627-2635. [CrossRef]

17. Aletayeb, S.M.; Jiryaei Sharahi, M.; Karimi, A. Dust stabilization using biological method against wind erosion. Arab. J. Geosci. 2021, 14, 1551. [CrossRef]

18. Liu, X.-J.; Fan, J.-Y.; Yu, J.; Gao, X. Solidification of loess using microbial induced carbonate precipitation. J. Mountain Sci. 2021, 18, 265-274. [CrossRef]

19. Liu, P.; Zhang, Y.; Tang, Q.; Shi, S. Bioremediation of metal-contaminated soils by microbially-induced carbonate precipitation and its effects on ecotoxicity and long-term stability. Biochem. Eng. J. 2021, 166, 107856. [CrossRef]

20. Zhu, J.; Shen, D.; Xie, J.; Tang, C.; Jin, B.; Wu, S. Mechanism of urea decomposition catalyzed by Sporosarcina pasteurii urease based on quantum chemical calculations. Mol. Simul. 2021, 47, 1335-1348. [CrossRef]

21. Ma, L.; Pang, A.P.; Luo, Y.; Lu, X.; Lin, F. Beneficial factors for biomineralization by ureolytic bacterium Sporosarcina pasteurii. Microb. Cell Fact. 2020, 19, 12. [CrossRef]

22. Garcia-Arroyo, F.E.; Gonzaga, G.; Munoz-Jimenez, I.; Blas-Marron, M.G.; Silverio, O.; Tapia, E.; Soto, V.; Ranganathan, N.; Ranganathan, P.; Vyas, U.; et al. Probiotic supplements prevented oxonic acid-induced hyperuricemia and renal damage. PLoS ONE 2018, 13, e0202901. [CrossRef]

23. Zhang, W.; Ju, Y.; Zong, Y.; Qi, H.; Zhao, K. In Situ Real-Time Study on Dynamics of Microbially Induced Calcium Carbonate Precipitation at a Single-Cell Level. Environ. Sci. Technol. 2018, 52, 9266-9276. [CrossRef]

24. Ghosh, T.; Bhaduri, S.; Montemagno, C.; Kumar, A. Sporosarcina pasteurii can form nanoscale calcium carbonate crystals on cell surface. PLoS ONE 2019, 14, e0210339. [CrossRef]

25. Christians, S.; Kaltwasser, H. Nickel-content of urease from Bacillus pasteurii. Arch. Microbiol. 1986, 145, 51-55. [CrossRef] [PubMed]

26. Nakano, H.; Takenishi, S.; Watanabe, Y. Purification and properties of urease from Brevibacterium ammoniagenes. Agric. Biol. Chem. 1984, 48, 1495-1502. [CrossRef]

27. Mulrooney, S.B.; Lynch, M.J.; Mobley, H.; Hausinger, R.P. Purification, characterization, and genetic organization of recombinant Providencia stuartii urease expressed by Escherichia coli. J. Bacteriol. 1988, 170, 2202-2207. [CrossRef] [PubMed]

28. Jones, B.; Mobley, H. Proteus mirabilis urease: Genetic organization, regulation, and expression of structural genes. J. Bacteriol. 1988, 170, 3342-3349. [CrossRef] [PubMed]

29. Marinkova, D.; Yotova, L.; Ringeard, J.-M.; Griesmar, P. Influence of Ni2+ on urease activity produced by biofilms of Arthrobacter oxydans 1388. Biotechnol. Biotechnol. Equip. 2014, 28, 266-270. [CrossRef] 
30. Loes, A.; Ruyle, L.; Arvizu, M.; Gresko, K.; Wilson, A.; Deutch, C. Inhibition of urease activity in the urinary tract pathogen Staphylococcus saprophyticus. Lett. Appl. Microbiol. 2014, 58, 31-41. [CrossRef]

31. Todd, M.; Hausinger, R. Purification and characterization of the nickel-containing multicomponent urease from Klebsiella aerogenes. J. Biol. Chem. 1987, 262, 5963-5967. [CrossRef]

32. Creaser, E.H.; Porter, R.L. The purification of urease from Aspergillus nidulans. Int. J. Biochem. 1985, 17, 1339-1341. [CrossRef]

33. Affan, M.-A.; Lee, D.-W.; Al-Harbi, S.M.; Kim, H.-J.; Abdulwassi, N.I.; Heo, S.-J.; Oh, C.; Park, H.-S.; Ma, C.W.; Lee, H.-Y. Variation of Spirulina maxima biomass production in different depths of urea-used culture medium. Braz. J. Microbiol. 2015, 46, 991-1000. [CrossRef] [PubMed]

34. Dhami, N.K.; Reddy, M.S.; Mukherjee, A. Biomineralization of calcium carbonates and their engineered applications: A review. Front. Microbiol. 2013, 4, 314. [CrossRef] [PubMed]

35. Stocks-Fischer, S.; Galinat, J.K.; Bang, S.S. Microbiological precipitation of $\mathrm{CaCO}_{3}$. Soil Biol. Biochem. 1999, $31,1563-1571$. [CrossRef]

36. Benini, S.; Kosikowska, P.; Cianci, M.; Mazzei, L.; Vara, A.G.; Berlicki, L.; Ciurli, S. The crystal structure of Sporosarcina pasteurii urease in a complex with citrate provides new hints for inhibitor design. J. Biol. Inorg. Chem. 2013, 18, 391-399. [CrossRef]

37. Nim, Y.S.; Wong, K.-B. The Maturation Pathway of Nickel Urease. Inorganics 2019, 7, 85. [CrossRef]

38. Zambelli, B.; Banaszak, K.; Merloni, A.; Kiliszek, A.; Rypniewski, W.; Ciurli, S. Selectivity of Ni (II) and Zn (II) binding to Sporosarcina pasteurii UreE, a metallochaperone in the urease assembly: A calorimetric and crystallographic study. JBIC J. Biol. Inorg. Chem. 2013, 18, 1005-1017. [CrossRef]

39. Carlsson, H.; Nordlander, E. Computational modeling of the mechanism of urease. Bioinorg. Chem. Appl. 2010, 2010 , e364891. [CrossRef]

40. Won, H.-S.; Lee, B.-J. Nickel-binding properties of the C-terminal tail peptide of Bacillus pasteurii UreE. J. Biochem. 2004, 136, 635-641. [CrossRef]

41. Mulrooney, S.B.; Ward, S.K.; Hausinger, R.P. Purification and properties of the Klebsiella aerogenes UreE metal-binding domain, a functional metallochaperone of urease. J. Bacteriol. 2005, 187, 3581-3585. [CrossRef] [PubMed]

42. Liu, X.; Zhang, Q.; Zhou, N.; Tian, Y. Expression of an Acid Urease with Urethanase Activity in E. coli and Analysis of Urease Gene. Mol. BioTechnol. 2017, 59, 84-97. [CrossRef] [PubMed]

43. Jahns, T. Ammonium/urea-dependent generation of a proton electrochemical potential and synthesis of ATP in Bacillus pasteurii. J. Bacteriol. 1996, 178, 403-409. [CrossRef] [PubMed]

44. Sazanov, L.A. A giant molecular proton pump: Structure and mechanism of respiratory complex I. Nat. Rev. Mol. Cell Biol. 2015, 16, 375-388. [CrossRef] [PubMed]

45. Pei, D.; Liu, Z.; Wu, W.; Hu, B. Transcriptome analyses reveal the utilization of nitrogen sources and related metabolic mechanisms of Sporosarcina pasteurii. PLoS ONE 2021, 16, e0246818. [CrossRef]

46. Graddy, C.M.R.; Gomez, M.G.; Kline, L.M.; Morrill, S.R.; DeJong, J.T.; Nelson, D.C. Diversity of Sporosarcina-like Bacterial Strains Obtained from Meter-Scale Augmented and Stimulated Biocementation Experiments. Environ. Sci. Technol. 2018, 52, $3997-4005$. [CrossRef]

47. Han, P.P.; Geng, W.J.; Li, M.N.; Jia, S.R.; Yin, J.L.; Xue, R.Z. Improvement of Biomineralization of Sporosarcina pasteurii as Biocementing Material for Concrete Repair by Atmospheric and Room Temperature Plasma Mutagenesis and Response Surface Methodology. J. Microbiol. Biotechnol. 2021, 31, 1-8. [CrossRef]

48. Achal, V.; Mukherjee, A.; Basu, P.C.; Reddy, M.S. Strain improvement of Sporosarcina pasteurii for enhanced urease and calcite production. J. Ind. Microbiol. Biotechnol. 2009, 36, 981-988. [CrossRef]

49. Zehner, J.; Royne, A.; Sikorski, P. Calcite seed-assisted microbial induced carbonate precipitation (MICP). PLoS ONE 2021, 16, e0240763. [CrossRef]

50. Sovljanski, O.; Pezo, L.; Tomic, A.; Ranitovic, A.; Cvetkovic, D.; Markov, S. Contribution of bacterial cells as nucleation centers in microbiologically induced $\mathrm{CaCO}_{3}$ precipitation-A mathematical modeling approach. J. Basic Microbiol. 2021, 61, 835-848. [CrossRef]

51. Harris, D.; Ummadi, J.G.; Thurber, A.R.; Allau, Y.; Verba, C.; Colwell, F.; Torres, M.E.; Koley, D. Real-time monitoring of calcification process by Sporosarcina pasteurii biofilm. Analyst 2016, 141, 2887-2895. [CrossRef] [PubMed]

52. Sun, X.; Miao, L.; Chen, R. The application of bio-cementation for improvement in collapsibility of loess. Int. J. Environ. Sci. Technol. 2020, 2607-2618. [CrossRef]

53. Rong, H.; Qian, C.-X. Binding Functions of Microbe Cement. Adv. Eng. Mater. 2015, 17, 334-340. [CrossRef]

54. Yu, X.; Qian, C.; Wang, X. Cementing mechanism of bio-phosphate cement. Sci. China Technol. Sci. 2015, 58, 1112-1117. [CrossRef]

55. Qian, C.; Yu, X.; Wang, X. A study on the cementation interface of bio-cement. Mater. Charact. 2018, 136, 122-127. [CrossRef]

56. Jadhav, U.U.; Lahoti, M.; Chen, Z.; Qiu, J.; Cao, B.; Yang, E.-H. Viability of bacterial spores and crack healing in bacteria-containing geopolymer. Constr. Build. Mater. 2018, 169, 716-723. [CrossRef]

57. Karimi, N.; Mostofinejad, D. Bacillus subtilis bacteria used in fiber reinforced concrete and their effects on concrete penetrability. Constr. Build. Mater. 2020, 230, 117051. [CrossRef]

58. Fang, L.; Niu, Q.; Cheng, L.; Jiang, J.; Yu, Y.-Y.; Chu, J.; Achal, V.; You, T. Ca-mediated alleviation of Cd ${ }^{2+}$ induced toxicity and improved $\mathrm{Cd}^{2+}$ biomineralization by Sporosarcina pasteurii. Sci. Total Environ. 2021, 787, 147627. [CrossRef] 
59. Badiee, H.; Sabermahani, M.; Tabandeh, F.; Saeedi Javadi, A. Application of an indigenous bacterium in comparison with Sporosarcina pasteurii for improvement of fine granular soil. Int. J. Environ. Sci. Technol. 2019, 16, 8389-8400. [CrossRef]

60. Jonkers, H.M. Self healing concrete: A biological approach. In Self Healing Materials; Springer: Berlin/Heidelberg, Germany, 2007; pp. 195-204.

61. Joshi, S.; Goyal, S.; Mukherjee, A.; Reddy, M.S. Microbial healing of cracks in concrete: A review. J. Ind. Microbiol. Biotechnol. 2017, 44, 1511-1525. [CrossRef]

62. Tayebani, B.; Mostofinejad, D. Self-healing bacterial mortar with improved chloride permeability and electrical resistance. Constr. Build. Mater. 2019, 208, 75-86. [CrossRef]

63. Lee, Y.S.; Park, W. Current challenges and future directions for bacterial self-healing concrete. Appl. Microbiol. BioTechnol. 2018, 102, 3059-3070. [CrossRef]

64. Chen, B.; Sun, W.; Sun, X.; Cui, C.; Lai, J.; Wang, Y.; Feng, J. Crack sealing evaluation of self-healing mortar with Sporosarcina pasteurii: Influence of bacterial concentration and air-entraining agent. Process Biochem. 2021, 107, 100-111. [CrossRef]

65. Kang, C.-H.; Choi, J.-H.; Noh, J.; Kwak, D.Y.; Han, S.-H.; So, J.-S. Microbially induced calcite precipitation-based sequestration of strontium by Sporosarcina pasteurii WJ-2. Appl. Biochem. Biotechnol. 2014, 174, 2482-2491. [CrossRef] [PubMed]

66. Mirshahmohammad, M.; Rahmani, H.; Maleki-Kakelar, M.; Bahari, A. A Comparative Study on Self-Healing Methods of Concretes by Sporosarcina pasteurii Bacteria. Res. Sq. 2021, rs-744114. [CrossRef]

67. Wang, J.; Van Tittelboom, K.; De Belie, N.; Verstraete, W. Use of silica gel or polyurethane immobilized bacteria for self-healing concrete. Constr. Build. Mater. 2012, 26, 532-540. [CrossRef]

68. Stuckrath, C.; Serpell, R.; Valenzuela, L.M.; Lopez, M. Quantification of chemical and biological calcium carbonate precipitation: Performance of self-healing in reinforced mortar containing chemical admixtures. Cem. Concr. Compos. 2014, 50, 10-15. [CrossRef]

69. Erşan, Y.Ç.; Da Silva, F.B.; Boon, N.; Verstraete, W.; De Belie, N. Screening of bacteria and concrete compatible protection materials Constr. Build. Mater. 2015, 88, 196-203. [CrossRef]

70. Ednie-Brown, P. bioMASON and the Speculative Engagements of Biotechnical Architecture. Archit. Des. 2013, 83, 84-91. [CrossRef]

71. Bernardi, D.; DeJong, J.; Montoya, B.; Martinez, B. Bio-bricks: Biologically cemented sandstone bricks. Constr. Build. Mater. 2014, 55, 462-469. [CrossRef]

72. Li, Y.; Wen, K.; Li, L.; Huang, W.; Bu, C.; Amini, F. Experimental investigation on compression resistance of bio-bricks. Constr. Build. Mater. 2020, 265, 120751. [CrossRef]

73. Lambert, S.E.; Randall, D.G. Manufacturing bio-bricks using microbial induced calcium carbonate precipitation and human urine. Water Res. 2019, 160, 158-166. [CrossRef] [PubMed]

74. Song, C.; Elsworth, D. Microbially Induced Calcium Carbonate Plugging for Enhanced Oil Recovery. Geofluids 2020, $2020,5921789$. [CrossRef]

75. Dubey, A.A.; Ravi, K.; Mukherjee, A.; Sahoo, L.; Abiala, M.A.; Dhami, N.K. Biocementation mediated by native microbes from Brahmaputra riverbank for mitigation of soil erodibility. Sci. Rep. 2021, 11, 15250. [CrossRef]

76. Li, P.; Qu, W. Bioremediation of historic architectural heritages by Sporosarcina pasteurii. In Proceedings of the 2011 International Conference on Electric Technology and Civil Engineering (ICETCE), Lushan, China, 22-24 April 2011; pp. $1084-1087$.

77. Maimaiti, B.; Chen, S.; Kasimu, A.; Simayi, Z.; Aierken, N. Urban spatial expansion and its impacts on ecosystem service value of typical oasis cities around Tarim Basin, northwest China. Int. J. Appl. Earth Obs. Geoinf. 2021, 104, 102554. [CrossRef]

78. Katebi, H.; Fahmi, A.; Ouria, A.; Babaeian Amini, A.; Kafil, H.S.; Cocozza, C. Microbial Surface Treatment of Sand with Sporosarcina pasteurii to Improve the Wind Erosion Resistance in Urmia Lake. Appl. Environ. Soil Sci. 2021, 2021, 1-11. [CrossRef]

79. Wulandari, K.D.; Ekaputri, J.J.; Triwulan; Kurniawan, S.B.; Primaningtyas, W.E.; Abdullah, S.R.S.; Ismail, N.I.; Imron, M.F. Effect of microbes addition on the properties and surface morphology of fly ash-based geopolymer paste. J. Build. Eng. 2021, 33, 101596. [CrossRef]

80. Rognoli, V.; Parisi, S. ICS Materiality: The phenomenon of interactive, connected, and smart materials as enablers of new materials experiences. In ICS Materials: Interactive, Connected, and Smart Materials; FrancoAngeli: Milan, Italy, 2021.

81. Li, M.; Cheng, X.; Guo, H. Heavy metal removal by biomineralization of urease producing bacteria isolated from soil. Int. Biodeterior. Biodegrad. 2013, 76, 81-85. [CrossRef]

82. Jain, S.; Arnepalli, D. Biominerlisation as a remediation technique: A critical review. Geotech. Character. Geoenviron. Eng. 2019, 16, 155-162.

83. Kim, Y.; Kwon, S.; Roh, Y. Effect of Divalent Cations (Cu, Zn, Pb, Cd, and Sr) on Microbially Induced Calcium Carbonate Precipitation and Mineralogical Properties. Front. Microbiol. 2021, 12, 646748. [CrossRef]

84. Jalilvand, N.; Akhgar, A.; Alikhani, H.A.; Rahmani, H.A.; Rejali, F. Removal of heavy metals zinc, lead, and cadmium by biomineralization of urease-producing bacteria isolated from Iranian mine calcareous soils. J. Soil Sci. Plant Nutr. 2020, 20, 206-219. [CrossRef]

85. Duarte-Nass, C.; Rebolledo, K.; Valenzuela, T.; Kopp, M.; Jeison, D.; Rivas, M.; Azócar, L.; Torres-Aravena, Á.; Ciudad, G. Application of microbe-induced carbonate precipitation for copper removal from copper-enriched waters: Challenges to future industrial application. J. Environ. Manag. 2020, 256, 109938. [CrossRef] [PubMed]

86. Gomez, M.G.; Martinez, B.C.; DeJong, J.T.; Hunt, C.E.; deVlaming, L.A.; Major, D.W.; Dworatzek, S.M. Field-scale bio-cementation tests to improve sands. Civ. Eng. 2015, 168, 206-216. [CrossRef] 
87. Qian, C.; Rong, H.; Yu, X.; Wang, X. Experiments on and predictions about properties of sand bonded by microbe cement. Sci. China Technol. Sci. 2016, 59, 1186-1193. [CrossRef]

88. Lapierre, F.M.; Schmid, J.; Ederer, B.; Ihling, N.; Büchs, J.; Huber, R. Revealing nutritional requirements of MICP-relevant Sporosarcina pasteurii DSM33 for growth improvement in chemically defined and complex media. Sci. Rep. 2020, 10, 22448. [CrossRef]

89. Al-Thawadi, S.; Cord-Ruwisch, R.; Bououdina, M. Consolidation of sand particles by nanoparticles of calcite after concentrating ureolytic bacteria in situ. Int. J. Green Nano Technol. 2012, 4, 28-36. [CrossRef]

90. Abo-El-Enein, S.A.; Ali, A.; Talkhan, F.N.; Abdel-Gawwad, H.A. Utilization of microbial induced calcite precipitation for sand consolidation and mortar crack remediation. HBRC J. 2012, 8, 185-192. [CrossRef]

91. Mortensen, B.M.; Haber, M.J.; DeJong, J.T.; Caslake, L.F.; Nelson, D.C. Effects of environmental factors on microbial induced calcium carbonate precipitation. J. Appl. Microbiol. 2011, 111, 338-349. [CrossRef]

92. Rong, H.; Qian, C.-x.; Li, L.-z. Influence of molding process on mechanical properties of sandstone cemented by microbe cement. Constr. Build. Mater. 2012, 28, 238-243. [CrossRef]

93. Tobler, D.J.; Maclachlan, E.; Phoenix, V.R. Microbially mediated plugging of porous media and the impact of differing injection strategies. Ecol. Eng. 2012, 42, 270-278. [CrossRef]

94. van Paassen, L.A.; Ghose, R.; van der Linden, T.J.M.; van der Star, W.R.L.; van Loosdrecht, M.C.M. Quantifying Biomediated Ground Improvement by Ureolysis: Large-Scale Biogrout Experiment. J. Geotech. Geoenviron. Eng. 2010, 136, 1721-1728. [CrossRef]

95. Tobler, D.J.; Cuthbert, M.O.; Greswell, R.B.; Riley, M.S.; Renshaw, J.C.; Handley-Sidhu, S.; Phoenix, V.R. Comparison of rates of ureolysis between Sporosarcina pasteurii and an indigenous groundwater community under conditions required to precipitate large volumes of calcite. Geochim. Cosmochim. Acta 2011, 75, 3290-3301. [CrossRef]

96. Zhu, T.; Paulo, C.; Merroun, M.L.; Dittrich, M. Potential application of biomineralization by Synechococcus PCC 8806 for concrete restoration. Ecol. Eng. 2015, 82, 459-468. [CrossRef]

97. Yu, X.; Qian, C.; Xue, B. Loose sand particles cemented by different bio-phosphate and carbonate composite cement. Constr. Build. Mater. 2016, 113, 571-578. [CrossRef]

98. Kahani, M.; Kalantary, F.; Soudi, M.R.; Pakdel, L.; Aghaalizadeh, S. Optimization of cost effective culture medium for Sporosarcina pasteurii as biocementing agent using response surface methodology: Up cycling dairy waste and seawater. J. Clean. Prod. 2020, 253, 120022. [CrossRef]

99. Chaparro, S.; Rojas, H.A.; Caicedo, G.; Romanelli, G.; Pineda, A.; Luque, R.; Martinez, J.J. Whey as an Alternative Nutrient Medium for Growth of Sporosarcina pasteurii and Its Effect on $\mathrm{CaCO}_{3}$ Polymorphism and Fly Ash Bioconsolidation. Materials 2021, 14, 2740. [CrossRef]

100. Achal, V.; Mukherjee, A.; Basu, P.C.; Reddy, M.S. Lactose mother liquor as an alternative nutrient source for microbial concrete production by Sporosarcina pasteurii. J. Ind. Microbiol. BioTechnol. 2009, 36, 433-438. [CrossRef]

101. Babakhani, S.; Fahmi, A.; Katebi, H.; Ouria, A.; Majnouni-Toutakhane, A.; Ganbarov, K.; Kafil, H.S. Non-sterile corn steep liquor a novel, cost effective and powerful culture media for Sporosarcina pasteurii cultivation for sand improvement. J. Appl. Microbiol. 2021, 130, 1232-1244. [CrossRef]

102. Yoosathaporn, S.; Tiangburanatham, P.; Bovonsombut, S.; Chaipanich, A.; Pathom-Aree, W. A cost effective cultivation medium for biocalcification of Bacillus pasteurii KCTC 3558 and its effect on cement cubes properties. Microbiol. Res. 2016, 186-187, 132-138. [CrossRef]

103. Meng, H.; Shu, S.; Gao, Y.; He, J.; Wan, Y. Kitchen waste for Sporosarcina pasteurii cultivation and its application in wind erosion control of desert soil via microbially induced carbonate precipitation. Acta Geotech. 2021. [CrossRef]

104. Chen, H.-J.; Huang, Y.-H.; Chen, C.-C.; Maity, J.P.; Chen, C.-Y. Microbial Induced Calcium Carbonate Precipitation (MICP) Using Pig Urine as an Alternative to Industrial Urea. Waste Biomass Valoriz. 2018, 10, 2887-2895. [CrossRef]

105. Omoregie, A.I.; Khoshdelnezamiha, G.; Senian, N.; Ong, D.E.L.; Nissom, P.M. Experimental optimisation of various cultural conditions on urease activity for isolated Sporosarcina pasteurii strains and evaluation of their biocement potentials. Ecol. Eng. 2017, 109, 65-75. [CrossRef] 